\title{
BILIARY ATRESIA: evaluation on two distinct periods at a reference pediatric service
}

\author{
Thais Costa Nascentes QUEIROZ, Alexandre Rodrigues FERREIRA, \\ Eleonora Druve Tavares FAGUNDES, Mariza Leitão Valadares ROQUETE and \\ Francisco José PENNA
}

\begin{abstract}
Context - Biliary atresia is a progressive, idiopathic, fibro-obliterative disease of the extrahepatic biliary tree that presents with biliary obstruction exclusively in the neonatal period. Objective - To assess the differences regarding age at referral, age at surgery, duration of propaedeutics and waiting time for surgery between two groups of infants in different periods. Methods Retrospective study of infants diagnosed with biliary atresia on two periods: 1983-1993 and 1998-2011. Results - Biliary atresia was diagnosed in 129 infants, being 48 in casuistic I and 81 in casuistic II. The median age at admission was 94 and 60 days, respectively $(P=0.0001)$. On evaluating patients who had undergone portoenterostomy before 120 days of age, no difference was observed regarding the duration of propaedeutics or waiting time for surgery $(P=0.15)$, but difference was found when comparing the age at surgery $(P=0.002)$. Among those infants with no biliary flow and without liver transplantation or death after 18 post-operative months, the estimated probability of survival was $44.6 \%$ and $38.7 \%$ in casuistics I and II, respectively. In casuistic I, all infants who showed biliary flow were alive during the observation period and, in casuistic II, 80.3\% were alive after 7 years of follow-up. Conclusions - Even though patients were admitted and treated earlier, it is clear that surgery could be done sooner. Delay in referral and timely propaedeutics were the main contributors.
\end{abstract}

HEADINGS - Biliary atresia. Hepatic portoenterostomy. Liver transplantation. Prognosis.

\section{INTRODUCTION}

Biliary atresia (BA) is a condition restricted to infants ${ }^{(38)}$, and is responsible for $50 \%$ of liver transplantation indications in the pediatric population ${ }^{(1,10)}$. It is a disease of both the intra- and extrahepatic bile ducts resulting from an inflammatory process which leads to the absence or progressive obliteration of ducts ${ }^{(26,37)}$. Etiopathogenic factors are unknown, however, multifactorial events may play a role ${ }^{(4)}$, in which genetic and environmental factors interact to promote the obliteration of the biliary tree ${ }^{(16,32)}$.

BA should always be recalled as a probable diagnosis when jaundice with cholestatic characteristics lasts beyond the 14th day of life ${ }^{(30)}$. The diagnosis is based, mainly, on the clinical, laboratorial, ultrasound image and histological evaluations. Rapid diagnosis and early surgical intervention - Kasai surgery - are the main factors described in literature for a favorable prognosis ${ }^{(5,20,39-41,47)}$, the reason why propaedeutics should be concluded before the first 6 weeks of life ${ }^{(25)}$. The establishment of biliary flow at the post-operative period can be achieved in $70 \%$ to $80 \%$ of patients who undergo surgery before 60 days of life; this becomes reduced to $25 \%$ in patients older than 90 days $^{(43)}$.

One of the greatest problems regarding BA is the late referral to the reference centers ${ }^{(8)}$, delaying propaedeutics which, in turn, leads to worse results. When evaluating BA cases from July 1983 through September $1993^{(37)}$, the Pediatric Gastroenterology Sector of Minas Gerais Federal University (HCUFMG) observed a delay in both referral to this service and surgical procedure. Since then, articles have been published in both national ${ }^{(3,10,11,21,36)}$ and regional ${ }^{(14)}$ medical journals, as well as by the regional medical society homepage ${ }^{(15)}$, for the acknowledgment and early referral of infants with cholestasis in an attempt to alert the medical population. Starting in 1998, together with those initiatives, and aiming at improving the results, a protocol has been established for the cholestasis propaedeutics so that diagnosis could be achieved faster.

This study assessed whether those changes altered the patients' age at referral, age at surgery, propaedeutic duration, and surgical results regarding biliary flow and survival rates between the periods of 1983-1993 and 1998-2011. 


\section{METHODS}

This is a retrospective study with infants diagnosed with BA at the HC-UFMG on two distinct periods: July 1983-September 1993 and January 1998-December 2011.

The following variables were evaluated: clinical (age at referral, gender, age at surgery, existence of post-Kasai bile flow, and survival rates), laboratorial (bilirubin dosage - total and direct, aspartate aminotransferase - AST; alanine aminotransferase - ALT), ultrasonographic and histopathological (pre- and intraoperative liver biopsy, evaluating fibrosis or cirrhosis). The anatomopathological analysis was conducted by experienced professionals of our institution.

When evaluating age at referral, all infants with BA diagnosed at the service in both periods were included. Regarding the other variables, only infants with BA submitted to portoenterostomy before 120 days of life were included. Those older than 120 days of life were excluded because they were referred directly to liver transplantation.

The time between commencement of propaedeutics after referral until execution of surgery was analyzed. During the 1983-1993 period, the propaedeutic protocol for investigation of cholestatic jaundice consisted of laboratory tests, abdominal ultrasound (US), duodenal tubing, hepatic histology and, occasionally, scintigraphy. After 1998, a protocol employing only US and hepatic histopathology (Figure 1) was developed, aiming at concluding the propaedeutics and indicating the surgery in a 5-day maximum period.

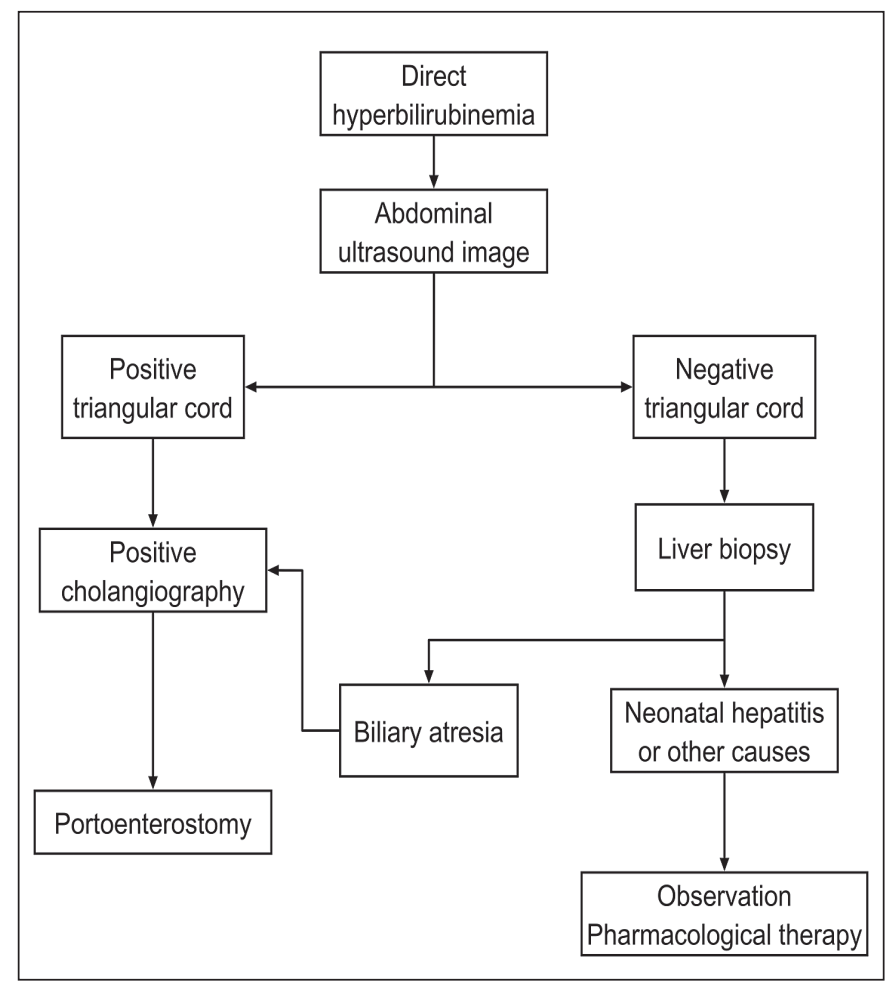

FIGURE 1. Protocol used at Hospital das Clínicas, Universidade Federal de Minas Gerais (HC-UFMG) in the approach of the cholestatic patient
US is performed after a 6-hour fast and is compatible with BA when the triangular cord is identified and/or associated with gallbladder alterations (absent or contracted); or findings compatible with polysplenia syndrome. The biopsy performed during the propaedeutics was considered suggestive of BA when ductal proliferation, portal fibrosis, and biliary plugs were present.

The presence of post-Kasai bile flow was considered positive when total bilirubin was lower than $3.2 \mathrm{mg} / \mathrm{dL} 3$ months after surgery ${ }^{(12,37)}$.

For data analysis, the Epi Info 6.04d software was used. Continuous variables without normal distribution were expressed by means of median and interquartile intervals of 25\%-75\% (IQ 25-75), and were compared using the MannWhitney non-parametric test. The probability was taken as significant when it was lower than 0.05 . For the assessment of survival time free from either death or transplantation, the KMSURV software was used. Deadline was May 31st 1994 for casuistic I, and December 31st 2011 for casuistic II. The starting date was, for both groups, portoenterostomy, while death or liver transplantation was considered the final event.

The research project was approved by the UFMG Research Ethics Committee, protocol number 77.0.203000-09.

\section{RESULTS}

One hundred twenty-nine infants diagnosed with BA were referred to the service, 48 during the period of 1983 through 1993 (casuistic I) and 81 during the period from 1998 to 2011 (casuistic II). With regard to age at referral, median in casuistic I was 94 days (IQ 25\%-75\% / 64.3-116.8), and for casuistic II was 60 days (IQ 25\%-75\% / 41.8-75) $(P=0.0001)$. All infants presented with jaundice, choluria, and hypocholia or fecal acholia.

\section{Evaluation of patients after surgery up to 120 days of age}

Ninety-five patients underwent Kasai surgery before 120 days; 27 in casuistic I (28.4\%) and $68(71.6 \%)$ in casuistic II.

Median time between the start of propaedeutics after admission and the Kasai surgery performance was 10.5 days (IQ 25\%-75\% / 7-16) in casuistic I, and 8 days (IQ 25\%-75\% / 6-14.3) in casuistic II $(P=0.15)$. Eight patients in casuistic I had a waiting time between hospitalization and surgery longer than 14 days. This was mainly due to infections, technical difficulty in duodenal tubing, treatment of complications related to the hepatic dysfunction, delay of complementary tests, such as US and/or liver biopsy, as well as delay in the execution of the surgery itself, due to institutional problems. In casuistic II, it was observed that the median time for the beginning of tests and surgery indication was 6 days (IQ $25 \%-75 \% / 4-8$ ). Nevertheless, despite surgery indication, patients who completed their preoperative workup had to wait 4 more days (median) until portoenterostomy performance (IQ 25\%-75\%/1-10). The main reasons for portoenterostomy delay were: clinical complications - ascitis, infection, 
hydroelectrolytic disorders, severe cardiopathy (six patients); US and/or biopsy non-suggestive of BA (eight patients); and patient-unrelated institutional problems (12 patients).

A difference was found $(P=0.002)$ when comparing the two periods regarding age at surgery (Table 1). Post-operative biliary flow was present in $36 \%$ of patients in casuistic I and $51.6 \%$ in casuistic II $(P=0.18)$.

In casuistic I, US was performed in $59.3 \%$ of the patients $(16 / 27)$ and the gallbladder could not be visualized in $62.5 \%$ of them (10/16). Evaluation of the triangular cord was not done at that time. Histopathological analysis was performed at intraoperative biopsies in 20 out of the 27 patients, all suggestive of BA, and cirrhosis was present in $25 \%$ of the samples.
In casuistic II, according to the 1998 protocol, all patients underwent US with $80.9 \%(55 / 68)$ compatible with $\mathrm{BA}$; in $30.9 \%$ of those cases, US was used as the sole diagnostic method for surgery indication. Preoperative biopsy was performed in $69.1 \%(47 / 68)$ of the patients and the results were compatible with BA in $76.6 \%$ (36) of them. Intraoperative biopsy was performed in all patients and BA was compatible in all cases. Hepatic cirrhosis was observed in $23 \%$ of the cases, with 1 patient among those submitted to surgery before 60 days of life and 13 among those older than that (Table 1).

Follow-up time presented a median of 11.5 months in casuistic I (IQ 25\%-75\% / 5-33.9) and 21.2 months in casuistic II (IQ 25\%-75\% / 7.4-58.6). When assessing the survival curve of patients with native liver and without postoperative

TABLE 1. Main clinical findings in 95 patients under 120 days of life

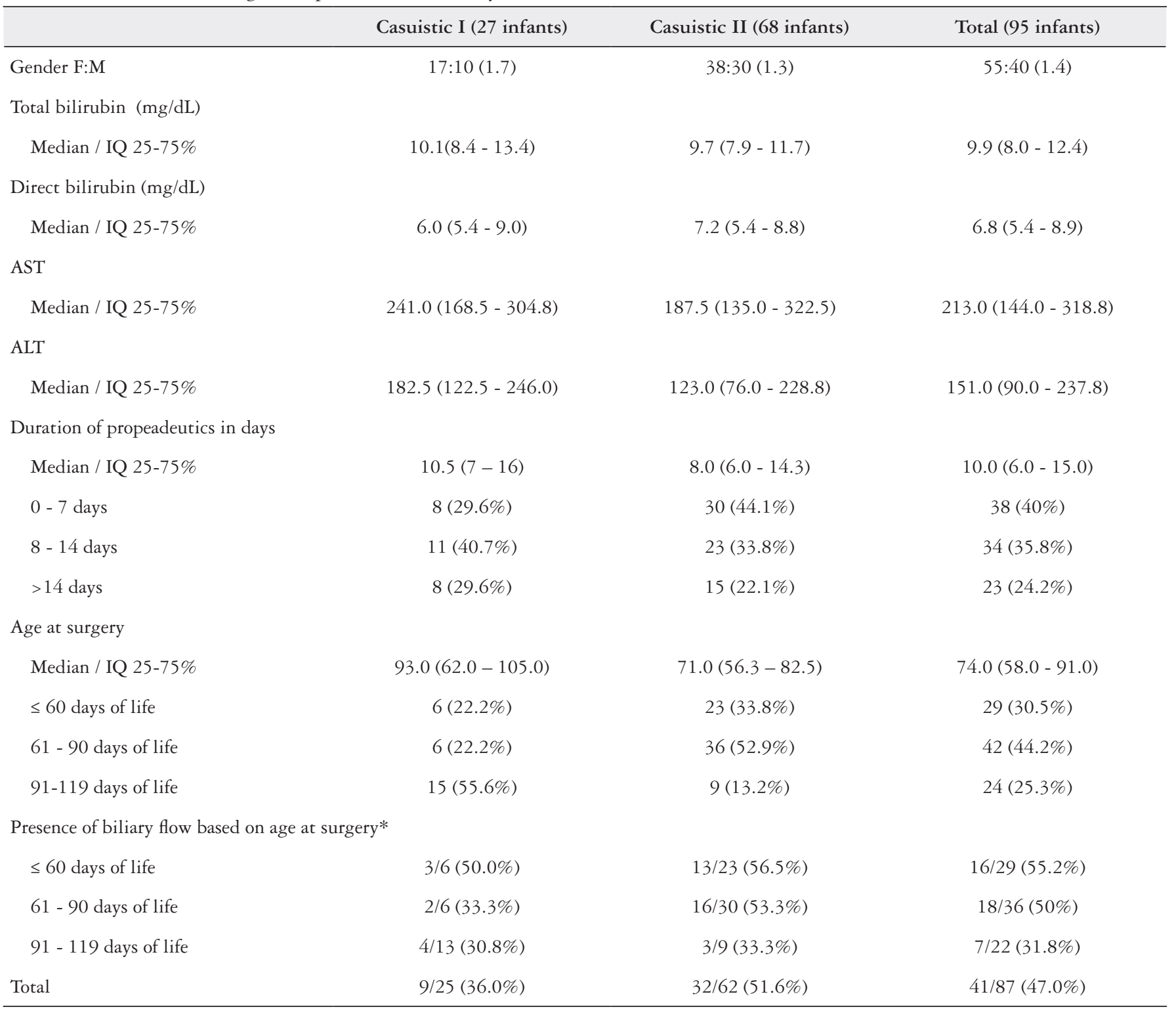

*Flow accessed in 25 patients in casuistic I and in 62 patients in casuistic II 
biliary flow, the estimated probability of survival was $74 \%$ for 6 months and $44.6 \%$ for 18 months in casuistic I. Seven patients died during follow-up. In casuistic II, the survival curve of patients with native liver and without postoperative biliary flow showed a survival estimate of $70 \%$ in 6 months, $59.8 \%$ in 12 months, and $38.7 \%$ in 18 months (Figure 2). Sixteen patients died and 11 were either transplanted or referred to liver transplantation.

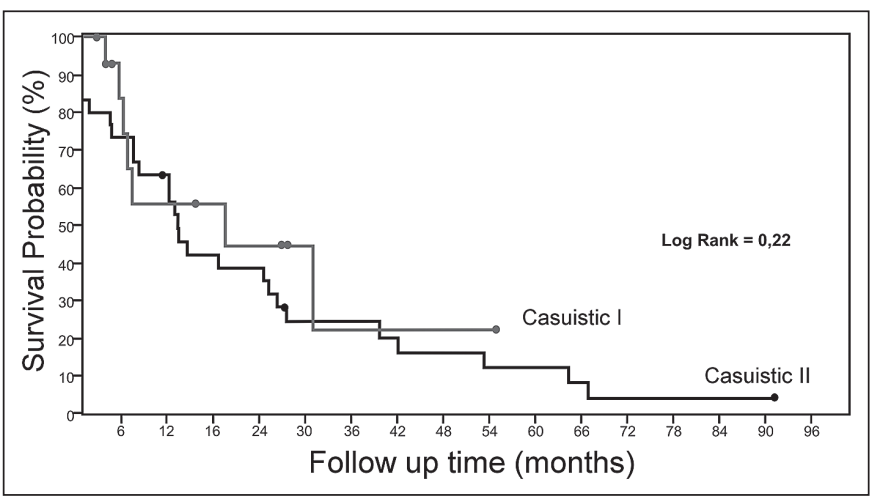

FIGURE 2. Survival with native liver in the group of patients who underwent Kasai surgery older than 120 days that evolved without biliary flow

On evaluating the survival curve of patients with postoperative biliary flow, all of them were alive during the follow-up period in casuistic I. In casuistic II, the estimated probability of survival with native liver in 18 months was of $93.1 \%$ and of $80.3 \%$ seven years after surgery (Figure 3 ). Two obits occurred in this casuistic group, and three were transplanted or referred to liver transplantation within the follow-up period.

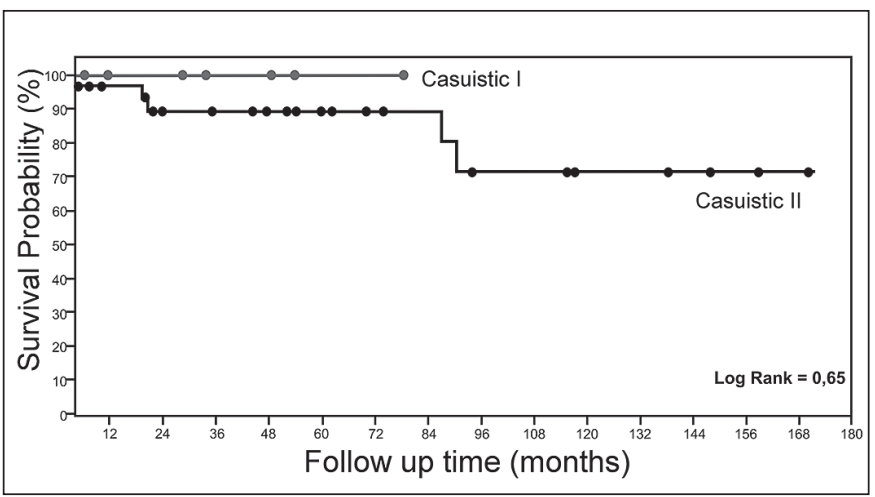

FIGURE 3. Survival with native liver in the group of patients who underwent Kasai surgery younger than 120 days that evolved with biliary flow

\section{DISCUSSION}

Neonatal cholestasis deserves prompt attention because it requires urgent propaedeutics in order to establish the diagnosis and perform the surgical correction of BA before 60 days of age. Late referral of suspected BA patients is one of the main factors for failure of surgical correction.
For that, bilirubin dosage in every newborn with jaundice after 2 weeks of birth is a universal guideline. Referral for surgery in due time remains a challenge all over the world ${ }^{(20)}$. A Canadian study reported a median of 55 days of age at referral ${ }^{(39)}$, whereas an American study reported a median of 61 days $^{(45)}$.

This study verified an earlier referral during the second period of observation, perhaps partly due to a greater awareness by health professionals, what, nonetheless, cannot be stated by this study design. Even in casuistic II, however, patients were referred past the ideal age. Literature has identified these possible factors for the delay at referral: lack of knowledge of the importance of an early diagnosis; incorrect handling by the pediatrician, that takes the jaundice as of little importance given the good nutritional state of patients; repeated pediatric consultations to assess the so-called physiological jaundice or breast milk jaundice; erroneous assessment of serum bilirubin levels; family's naive interpretation of jaundice as a physiological event and use of home remedies as therapeutic measures in jaundice, therefore retarding the consultation with a physician; and, ultimately, a delay caused by the difficulties in accessing medical assistance ${ }^{(30)}$. Davenport et al. ${ }^{(9)}$, when analyzing patients at King's College Hospital, observed that the main motives for late diagnosis and treatment were failure of parents in searching medical evaluation for the persistent jaundice, delay in transference or a wrong diagnosis by the general physician, and a liver biopsy that did not suggest BA initially.

Despite a consensus about the importance of an early Kasai surgery, this procedure is still performed quite late in Brazil. Encompassing all different geographical regions in this country, it was shown that the average age at surgery was of 82.6 days ${ }^{(11)}$, well above what is seen in literature: 54 days in the United Kingdom ${ }^{(8)}, 57$ days in France ${ }^{(40)}, 61$ days in the United States of America ${ }^{(42)}$, and 68 days in Switzerland ${ }^{(47)}$. At the HC-UFMG, during the last 14 years, a significant improvement occurred in patients' surgical age being reduced from 93 to 71 days. Despite this improvement, such a result still remains unsatisfactory.

Postoperative biliary flow is strictly connected to the time of the portoenterostomy ${ }^{(1)}$. If the surgery is performed within the 60 first days of life, the procedure provides drainage of bile into the intestines in at least $70 \%$ to $80 \%$ of cases. When done between 60 and 90 days of life, approximately $40 \%$ to $50 \%$ will develop biliary flow. After 90 days of life, up to $25 \%$ will evolve with biliary draining, whereas, when performed after 120 days of life, only $10 \%$ to $20 \%$ of patients will exhibit biliary flow. No difference was observed in postoperative biliary flow between the two groups, probably due to the small sample of patients having early surgery, as demonstrated by an older age at surgery in both periods.

The establishment of postoperative biliary flow is the most important predictor of survival in $\mathrm{BA}^{(17)}$, with a 10year survival rate varying from $73 \%$ to $92 \%$ in patients who became jaundice-free after surgery, while in those with permanent jaundice and inadequate biliary flow the 3-year survival is $20 \%{ }^{(1)}$, a data similar to the ones found in this 
study. The introduction of liver transplantation in BA treatment can interrupt the evolution of the condition into an unfavorable outcome for patients without biliary drainage. This reduces the survival rates of native-liver infants, because liver transplantation was considered a final event in our study.

When analyzing the 1983-1993 period, there was a great delay between initiation of propaedeutics at the service and performance of portoenterostomy, as well as the age at the procedure, which was beyond recommendation ${ }^{20}$, ${ }^{27,40)}$. In view of this evidence and in order to improve the age at surgery, associated to the experience obtained by the service $^{(35)}$ from the data found in literature emphasizing the identification of the triangular cord on $\operatorname{US}^{(19,22,23,33,44)}$ and importance of liver biopsy ${ }^{(13,23,29,33,46)}$, a guideline was established in 1998 in which US and hepatic histology were used during propaedeutics, withdrawing duodenal tubing and scintigraphy from the routine evaluation. This protocol targeted the confirmation of the disease and execution of the surgery within 5 days.

If one considers the propaedeutic time as the period between admission and surgery indication (and not surgery execution), the association of US with histopathology achieved evident satisfactory results, with a median of 6 days, closer to which has been recommended in literature ${ }^{(23)}$. Surgery can be postponed due to clinical complications that cannot be directly modifiable, but also by institution-related issues that can be solved in order to improve outcome. Concerning propaedeutic time, even though a decrease was observed in casuistic II, it was devoid of statistical significance. The establishment of this protocol was responsible for that improvement and the propaedeutic time in casuistic II would probably be lesser if surgery was performed promptly. We believe that not performing duodenal tubing and scintigraphy, coupled with greater access to US, were the main factors responsible for the reduction in propaedeutic time. Hepatobiliary scintigraphy has a limited value because it presents with high sensitivity, often at $100 \%$, and has disagreeing values about its specificity, varying from $40 \%$ to $100 \%{ }^{(2)}$. Although duodenal tubing has been reported as a useful method for BA diagnosis, with a specificity of $93.7 \%$ and a sensitivity varying from $97.3 \%$ to $100 \%{ }^{(24-34)}$, it was responsible for the delay in propaedeutics at this institution ${ }^{(37)}$.

It is mandatory to improve the agility in diagnosis, increase the efficiency of the diagnosis process, and decrease the time gap between referral and portoenterostomy. This implicates optimization in clinical and laboratorial tests, as well as in image and histopathological exams, since no isolated test is able to diagnose $\mathrm{BA}^{(31)}$. $\mathrm{US}^{(19,22,33,44)}$ owns the diagnostic accuracy of $72.5 \%$ to $100 \%$, and the histopathology ${ }^{(13,23,29,33,46)}$ shows it between $86.5 \%$ and $96.8 \%$. US and hepatic histology, together with clinical symptoms, particularly persistent fecal acholia, were consolidated at the HCUFMG as reliable resources for the preoperative diagnosis of extrahepatic cholestasis, specially BA ${ }^{(35)}$.

Despite the improvement in patients' age at admission, late referral of suspected BA is still one of the main factors delaying the surgical procedure in our premises. Thus, the identification of signals of cholestasis (choluria, hypocholia, or fecal acholia) paired with bilirubin dosage in every infant who sustains jaundice after 14 days of life is the cornerstone. The importance of feces color analysis should be emphasized either by means of campaigns such as the "Yellow Alert"(28) or by use of the chromatic scale, presented in the Child's Health Booklet in Brazil ${ }^{(3)}$. Such information is highly necessary and must reach not only the parents, but healthcare providers as well. Those strategies proved very successful in countries that reduced the late referral of patients, improving portoenterostomy results and, consequently, decreasing the need of pediatric liver transplantations $s^{(6,7,18)}$. We should also pursue strategies to further reduce propaedeutic time and hasten the execution of portoenterostomy, as the time elapsed between them is still very long.

Queiroz TCN, Ferreira AR, Fagundes EDT, Roquete MLV, Penna FJ. Atresia biliar: avaliação em dois períodos distintos em um serviço de referência. Arq Gastroenterol. 2014,51(1):53-8.

RESUMO - Contexto - A atresia biliar é uma doença progressiva, idiopática, fibro obliterativa, da vias bilares extra hepáticas que se apresenta com obstrução biliar exclusivamente no periodo neonatal. Objetivos - Caracterizar duas épocas distintas visando avaliar se ocorreram alterações quanto a idade de encaminhamento das crianças, idade cirúrgica, duração do tempo entre internação e realização da cirurgia de Kasai, resultados cirúrgicos quanto a presença de fluxo biliar e sobrevida entre dois períodos. Métodos - Estudo retrospectivo de crianças com diagnóstico de atresia biliar em dois períodos: 1983-1993 e 1998-2011. Resultados - Foram admitidas 129 crianças com diagnóstico de AB, 48 (casuística I) e 81 (casuística II), com idade de admissão mediana de 94 e 60 dias, nas casuísticas I e II, respectivamente $(P=0,0001)$. Na avaliação dos pacientes submetidos à portoenterostomia com idade até 120 dias de vida, não houve diferença em relação ao tempo entre internação e realização da cirurgia de Kasai $(P=0,15)$, mas ocorreu ao comparar a idade à cirurgia entre os dois períodos $(P=0,002)$. A probabilidade estimada de sobrevida dos pacientes sem fluxo biliar livre de transplante ou óbito em 18 meses foi de 44,6\%, 38,7\% nas casuísticas I e II, respectivamente. Com fluxo biliar, todos estavam vivos ao longo do seguimento da casuística I e 80,3\% em sete anos na casuística II. Conclusões - Apesar dos pacientes chegarem mais cedo e serem submetidos à portoenterostomia, ainda se opera tarde. Encaminhamento tardio e a propedêutica prolongada são os principais contribuintes. Quanto maior a idade cirúrgica, menor a probabilidade de se obter fluxo biliar e consequentemente menor sobrevida.

DESCRITORES - Atresia biliar. Portoenterostomia hepática. Transplante de fígado. Prognóstico. 


\section{REFERENCES}

1. Balistreri WF, Grand R, Hoofnagle JH, Suchy FJ, Ryckman FC, Perlmutter DH, Sokol RJ. Biliary atresia: current concepts and research directions. Summary of a symposium. Hepatology. 1996;23:1682-92.

2. Bassett MD, Murray KF. Biliary atresia: recent progress. J Clin Gastroenterol. 2008;42:720-9

3. Bezerra JA. Biliary atresia in Brazil: where we are and where we are going. J Pediatr (Rio J). 2010;86:445-7.

4. Bezerra JA. The next challenge in pediatric cholestasis: deciphering the pathogenesis of biliary atresia. J Pediatr Gastroenterol Nutr. 2006;43:S23-9.

5. Chardot C, Carton M, Spire-Bendelac N, Le Pommelet C, Golmard JL, Auvert B. Prognosis of biliary atresia in the era of liver transplantation: French national study from 1986 to 1996. Hepatology. 1999:30:606-11.

6. Chardot C, Serinet M-O. Prognosis of biliary atresia: what can be further improved? J Pediatr. 2006;148:432-5.

7. Chen SM, Chang MH, Du JC, Lin CC, Chen AC, Lee HC, Lau BH, Yang YJ, Wu TC, Chu CH, Lai MW, Chen HL. Screening for biliary atresia by infant stool color card in Taiwan. Pediatrics. 2006;117:1147-54.

8. Davenport M, De Ville de Goyet J, Stringer MD, Mieli-Vergani G, Kelly DA, McClean P, Spitz L. Seamless management of biliary atresia in England and Wales (1999-2002). Lancet. 2004;363:1354-1357.

9. Davenport M, Puricelli V, Farrant P, Hadzic N, Mieli-Vergani G, Portmann B, Howard ER. The outcome of the older ( $>$ or $=100$ days) infant with biliary atresia. J Pediatr Surg 2004;39:575-81.

10. Carvalho E, Ivantes CAP, Bezerra JA. Extrahepatic biliary atresia: current concepts and future directions. J Pediatr (Rio J). 2007;83:105-20.

11. Carvalho E, Santos JL, Silveira TR, Kieling CO, Silva LR, Porta G, Miura IK, Tommaso AMA, Brandao MAB, Ferreira AR, Macedo JRD, Neto JTA. Biliary atresia: the Brazilian experience. J Pediatr (Rio J). 2010;86:473-9.

12. Ecoffey C, Rothman E, Bernard O, Hadchouel M, Valayer J, Alagille D. Bacterial cholangitis after surgery for biliary atresia. J Pediatr. 1987;111:824-9.

13. Faweya AG, Akinyinka OO, Sodeinde O. Duodenal intubation and aspiration test: utility in the differential diagnosis of infantile cholestasis. J Pediatr Gastroenterol Nutr 1991;13:290-2.

14. Ferreira AR, Fagundes EDT, Roquete MLV, Penna FJ. Colestase neonatal. Revista Médica de Minas Gerais. 2005;15:14-20.

15. Ferreira AR, Roquete MLV, Fagundes EDT, Penna FJ. Colestase do lactente. 2010 Available at: http://www.smp.org.br/visualizacao-de-base-de-dados-cientificos/ pt-br/ler/51/colestase-do-lactente. Accessed January 6, 2013.

16. Hartley JL, Davenport M, Kelly DA. Biliary atresia. Lancet. 2009;374:1704-13.

17. Houwen RH, Zwierstra RP, Severijnen RS, Bouquet J, Madern G, Vos A, Bax NM Heymans HS, Bijleveld CM. Prognosis of extrahepatic biliary atresia. Arch Dis Child. 1989;64:214-8.

18. Hsiao CH, Chang MH, Chen HL, Lee HC, Wu TC, Lin CC, Yang YJ, Chen AC Tiao MM, Lau BH, Chu CH, Lai MW. Universal screening for biliary atresia using an infant stool color card in Taiwan. Hepatology. 2008;47:1233-240.

19. Kanegawa K, Akasaka Y, Kitamura E, Nishiyama S, Muraji T, Nishijima E, Satoh $\mathrm{S}$, Tsugawa C. Sonographic diagnosis of biliary atresia in pediatric patients using the "triangular cord" sign versus gallbladder length and contraction. AJR Am J Roentgenol. 2003;181:1387-1390.

20. Karrer FM, Lilly JR, Stewart BA, Hall RJ. Biliary atresia registry, 1976 to 1989. J Pediatr Surg. 1990;25(10):1076-80- discussion 1081.

21. Kieling CO, Santos JL, Vieira SMG, Ferreira CT, Linhares ARR, Lorentz AL, Silveira TR. Biliary atresia: we still operate too late. J Pediatr (Rio J). 2008;84:436-41.

22. Kotb MA, Kotb MA, Sheba MF, El-Koofy NM, El-Karaksy HM, Abdel-Kahlik MK, Abdalla A, El-Regal ME, Warda R, Mostafa H, Karjoo M, Kader HHA. Evaluation of the triangular cord sign in the diagnosis of biliary atresia. Pediatrics. 2001;108:416-20.

23. Lai MW, Chang MH, Hsu SC, Hsu HC, Su CT, Kao CL, Lee CY. Differential diagnosis of extrahepatic biliary atresia from neonatal hepatitis: a prospective study. J Pediatr Gastroenterol Nutr 1994;18:121-7.

24. Larrosa-Haro A, Caro-López AM, Coello-Ramírez P, Zavala-Ocampo J, Vázquez-Camacho G. Duodenal tube test in the diagnosis of biliary atresia. J Pediatr Gastroenterol. Nutr 2001;32:311-5.
25. Lilly JR, Karrer FM. Contemporary surgery of biliary atresia. Pediatr Clin North Am. 1985;32:1233-46.

26. Luo Y, Zheng S. Current concept about postoperative cholangitis in biliary atresia. World J Pediatr. 2008;4:14-9.

27. Lykavieris P, Chardot C, Sokhn M, Gauthier F, Valayer J, Bernard O Outcome in adulthood of biliary atresia: a study of 63 patients who survived for over 20 years with their native liver. Hepatology. 2005;41:366-71.

28. Mackinlay GA. Jaundice persisting beyond 14 days after birth. BMJ. 1993;306:1426-7.

29. Manolaki AG, Larcher VF, Mowat AP, Barrett JJ, Portmann B, Howard ER The prelaparotomy diagnosis of extrahepatic biliary atresia. Arch Dis Child 1983;58:591-4.

30. Mieli-Vergani G, Howard ER, Portman B, Mowat AP. Late referral for biliary atresia--missed opportunities for effective surgery. Lancet. 1989;1:421-3.

31. Moyer V, Freese DK, Whitington PF, Olson AD, Brewer F, Colletti RB, Heyman MB. Guideline for the evaluation of cholestatic jaundice in infants: recommendations of the North American Society for Pediatric Gastroenterology, Hepatology and Nutrition. J Pediatr Gastroenterol Nutr. 2004;39:115-28.

32. Pakarinen MP, Rintala RJ. Surgery of biliary atresia. Scand J Surg. 2011;100:49-53

33. Park WH, Choi SO, Lee HJ, Kim SP, Zeon SK, Lee SL. A new diagnostic approach to biliary atresia with emphasis on the ultrasonographic triangular cord sign: comparison of ultrasonography, hepatobiliary scintigraphy, and liver needle biopsy in the evaluation of infantile cholestasis. J Pediatr Surg 1997;32:1555-9.

34. Penna FJ, Leão E. Duodenal intubation in the differential diagnosis of obstructive jaundice in infants. Arq Gastroenterol. 1982;19:143-6.

35. Roquete MLV, Ferreira AR, Fagundes EDT, Castro LPF, Silva RAP, Penna FJ. Accuracy of echogenic periportal enlargement image in ultrasonographic exams and histopathology in differential diagnosis of biliary atresia. J Pediatr (Rio J) 2008;84:331-6.

36. Roquete MLV. [Neonatal cholestasis]. J Pediatr (Rio J). 2000;76:S187-97.

37. Roquete MLV. Atresia biliar extra-hepática: experiência de 10 anos no Hospital das Clínicas da UFMG. [Dissertation]. Belo Horizonte: Faculdade de Medicina da UFMG; 1994.

38. Santos dos JL, Cerski CT, da Silva VD, de Mello ES, Wagner MB, da Silveira TR. [Factors related to the post-portoenterostomy prognosis of biliary atresia] J Pediatr (Rio J). 2002;78:341-6.

39. Schreiber RA, Barker CC, Roberts EA, Martin SR, Alvarez F, Smith L, Butzner JD, Wrobel I, Mack D, Moroz S, Rashid M, Persad R, Levesque D, Brill H, Bruce G, Critch J. Biliary atresia: the Canadian experience. J Pediatr 2007;151:659-65.

40. Serinet MO, Broué P, Jacquemin E, Lachaux A, Sarles J, Gottrand F, Gauthier F, Chardot C. Management of patients with biliary atresia in France: results of a decentralized policy 1986-2002. Hepatology. 2006;44:75-84.

41. Serinet MO, Wildhaber BE, Broué P, Lachaux A, Sarles J, Jacquemin E, Gauth ier F, Chardot C. Impact of age at Kasai operation on its results in late childhood and adolescence: a rational basis for biliary atresia screening. Pediatrics 2009;123:1280-6.

42. Shneider BL, Brown MB, Haber BA, Whitington PF, Schwarz KB, Squires RH, Bezerra JA, Shepherd RW, Rosenthal P, Hoofnagle JH, Sokol RJ. A multicenter study of the outcome of biliary atresia in the United States, 1997 to 2000. J Pediatr. 2006; 148:467-4.

43. Sokol RJ, Mack C, Narkewicz MR, Karrer FM. Pathogenesis and outcome of biliary atresia: current concepts. J Pediatr Gastroenterol Nutr. 2003;37:4-21.

44. Tan Kendrick AP, Phua KB, Ooi BC, Subramaniam R, Tan CE, Goh AS. Making the diagnosis of biliary atresia using the triangular cord sign and gallbladder length. Pediatr Radiol. 2000;30:69-73.

45. Tarr PI, Haas JE, Christie DL. Biliary atresia, cytomegalovirus, and age at referral. Pediatrics. 1996;97:828-31.

46. Tolia V, Dubois RS, Kagalwalla A, Fleming S, Dua V. Comparison of radionuclear scintigraphy and liver biopsy in the evaluation of neonatal cholestasis. J Pediatr Gastroenterol Nutr. 1986;5:30-4.

47. Wildhaber BE, Majno P, Mayr J, Zachariou Z, Hohlfeld J, Schwoebel M, Kistler W, Meuli M, Coultre CL, Mentha G, Belli D, Chardot C. Biliary atresia: Swiss national study, 1994-2004. J Pediatr Gastroenterol Nutr. 2008;46:299-307. 